\title{
Abstract not submitted for online publication
}

From Epigenetics and Chromatin: Interactions and processes

Boston, MA, USA. 11-13 March 2013

\section{Abstract not submitted for online publication}

Published: 18 March 2013

doi:10.1186/1756-8935-6-S1-P84

Cite this article as: : Abstract not submitted for online publication.

Epigenetics \& Chromatin 2013 6(Suppl 1):P84.

Submit your next manuscript to BioMed Central and take full advantage of:

- Convenient online submission

- Thorough peer review

- No space constraints or color figure charges

- Immediate publication on acceptance

- Inclusion in PubMed, CAS, Scopus and Google Scholar

- Research which is freely available for redistribution 